\title{
Why you should boycott the Russians
}

\section{A plea to western scientists \\ from exiled dissident Valentin Turchin}

LAST February, on the first anniversary of the detention of Professor Yurii Orlov, a well-known Soviet physicist, in Moscow's Lefortovo Prison, I wrote a letter about his case to all physicists who are members of the US National Academy of Sciences (NAS) and to certain other physicists. I suggested that American scientists demand that they send a representative to Orlov's trial. If the Soviet authorities refused this request the scientists should boycott co-operation with the Soviet Union in physics until Orlov is released. I noted that Orlov is the first member of an academy of sciences in the Soviet Union to be arrested on political grounds since Stalin's death, and that the charge against him had recently been reclassified, so that instead of three years in prison he has now been sentenced to seven years of strict regime imprisonment plus five years in internal exile.

I have received positive answers to my letter from 70 physicists, and I am very thankful to them for taking to heart a Russian colleague's fate. They are, of course, a minority. I also received two important letters, which listed arguments against a boycott. One is from the President of the NAS, Dr Philip Handler; the other from three professors of MIT: Herman Feshbach, Francis E. Low and Victor F. Weisskopf. I believe a discussion of the questions they raise is timely and of general interest.

Feshbach et al. argue that "the Soviet physicists rather than the authorities will be punished by cutting off contacts." The implication that the authorities will not be punished by a boycott is wrong. The boycott I suggest would be directed against official relationships not against scientific communication. It would not impair the flow of scientific publications, by far the main source of information for Soviet scientists; its most immediate result would be to cancel a number of official Soviet-American exchanges. A foreign trip is a fairly sweet carrot in the Soviet policy of whip and carrot by which it creates an obedient group of scientific leaders. The authorities would not welcome the loss of this carrot. A boycott would also be a tremendous blow to government prestige back home. They would find it difficult to explain.

Now let us turn to the scientists. The boycott would be a punishment for only some of them. Soviet citizens are divided into two categories, vyiezdnyie and nevyiezdnyie. The boycott would punish those scientists belonging to the first category, who are allowed by the authorities (or rather by the KGB, who always have a veto) to go abroad and to take part in joint projects. Is this a very cruel and unjust punishment compared to Orlov's fate? When Orlov was arrested, not a single person from the scientific establishment in the Soviet Union showed the slightest concern about what was done to him. The most salient and immediate reason was because they did not want to lose their chances (actual or potential) of going abroad. I believe this behaviour forfeits one's moral right to foreign trips. Not that I seek to deprive these people of forcign trips to punish them, but I do not see why this side-effect should prevent us from taking resolute action on behalf of such persons as Yurii Orlov, Sergei Kovalev and others. Soviet scientists who understand this would not be offended; those who do not understand forfeit their right once more. The majority of the scientists, the nevyiezdnyie who are not permitted foreign trips or who do not want to behave in the way necessary to earn such permission, will welcome the boycott as an effort to rescue a prisoner of conscience. They will lose little, if anything.

My correspondents' second argument is that the boycott would hamper the visits of western scientists to the USSR, which are "important for actions in support of those who are being persecuted by the Soviet authorities but who have not as yet been formally charged". But a boycott on behalf of arrested scientists is the best, if not the only, way to protect those who are not yet arrested! Visits to Sovict scientists support them only to the extent that resolute actions may follow. Boycotting official Soviet ties does not mean severing personal ties with persecuted scientists. On the contrary, they should be strengthened. Exchange of letters and materials and help with publications are priceless. And after all, one can visit the Soviet Union as a tourist.

The third argument is that the boycott would impair the exchange of ideas and in particular, those ideas which "may hopefully contribute toward a better and peaceful world". I think that socially important ideas are most often communicated through the printed word or other mass media, not through brief conversations. Westerners, when they are in the Soviet Union, prefer to "do as the Romans do" so there is no "exchange of behaviour" during official visits. They justify their behaviour by referring to their position as guests, and also by saying that "you must not mix science with politics" and that "after all, every nation has its own customs". Soviet citizens, when they visit the West and return, do not change a bit, with very rarc exceptions. Only those who are sure not to change receive permission to travel.

Restriction of free communication is already the main principle of the Soviet rulers. You in the West accept this model without serious attempts to insist on your model. Did you ever reject a Soviet delegation to a conference because the brightest scientist you had invited had not received permission to attend on 'political' grounds, that is, most often for his love of free exchange of information? You accept and obey the Soviet model in all your relationships with the Soviets; thereby you help to perpetuate it.

Can you press the Soviet system at least to start changing the model? Yes, you can. But you have only one serious means of pressure: to threaten and exercise specific boycotts and refusals. In so doing, you still further diminish the exchange of information, and this looks paradoxical. But scientists in the 20th century are not surprised by paradoxes. The solution is simple: you would be reducing those forms of exchange which are most important for the rulers, not for the ruled. Orloy was arrested for giving publicity to information on violations of the Helsink Accord. Other people in the Soviet Union are arrested for possessing books published in the West. Do you think you fight for freedom of information when you reject a boycott in order to have a conference in Soviet Georgia instead of, say, Norway, or to give Mr Gvishiani (Premier Kosygin's son-in-law) an opportunity to run a department in a joint institute in Austria?

Another argument against boycotts and other resolute action which turns up often, is the fragility of detente and the peril of a global nuclear war. In answer to my letter, Dr Handler wrote:

"Since our first formal protest to the Soviet Academy on behalf of Benjamin Levich, a protest that has bcen followed by so many others, I have understood that the time might come when the course of events or the compelling sense of justice might bring us to the point of terminating our programmes of exchange and cooperation with the Soviet Union in matters scientific." 
Nevertheless, Dr Handler rejects the idea of a boycott on the Academy level at the present moment. He continues:

\begin{abstract}
"Meanwhile, I have continued to hope, albeit with little confidence, that the Soviet leadership would learn that a great nation can easily tolerate dissent and discussion whereas repression must inevitably breed revolt. More importantly, I have recognised how fragile is detente ... Unfortunately, the alternative to detente appears to be the vision of two nuclear-armed superpowers on a collision course, the ultimate consequences of which are simply too awful to contemplate. Given these unstable circumstances, formal interruption of our scientific relations could have the effect of throwing a switch from detente back to the cold war which is but a prelude to a hot one ... Thus, whereas I view the situation of Orlov-like the circumstances of Kovalev, Scharansky, Ginzburg and the deteriorating personal circumstances of Sakharov-as a matter of the highest priority and deepest concern, I have not yet found the course of wisdom to be formal interruption of our scientific relationship although that possibility remains."
\end{abstract}

I am fully conscious of Dr Handler's responsibility. I hope that boycott on the level of individuals, laboratories or universities will be wide enough to become effective. I hope also that if this turns out to be insufficient, the NAS will step in--a possibility that is indicated in Dr Handler's letter. But $I$ think that the fear of a direct link from scientific boycott to nuclear war is exaggerated.

The cause of strain and instability in relations between the two superpowers lies in the character of the Soviet regime. The rulers of the USSR implement a way of life which they call 'socialism', but which in fact is simply a totalitarian dictatorship by the Communist Party. The rulers claim that the system is the most democratic in the

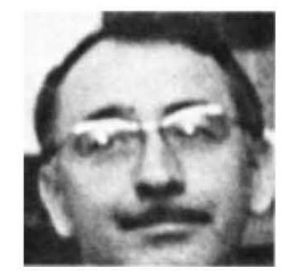

'If you see totalitarianism as a horrible threat to mankind and your mind rebels at what the Soviets are doing to Orlov and others, you will certainly not reject a boycott, although aware Valentin Turchin of its double-edged nature'

world and that they are 'true representatives' of the people. But they know that they are not. Therefore, they must jusify their 'socialism' compared to western democracy; they must justify their firm hold on absolute power. Now, failing to create higher living standards, they have only one way to do that: to demonstrate that western democracy (which they equate with 'capitalisn') does not work. This is why they subvert any constructive initiative on a world scale.

They are also obliged to behave as imperialists. The leadership carefully and insistently cultivates imperialistic feelings in the population, and not without success. For me, one of the greatest shocks in the 1968 invasion of Czechoslovakia was that the overwhelming majority of people in the USSR really welcomed the invasion. Soviet man unconsciously compensates for his abject personal position by feeling like part of a superpower.

Of course, Soviet leaders do not want nuclear war; they are not madmen. But, having a vested interest in international instability, they create conditions which may lead to nuclear war accidentally, without their explicit wish. This is the real danger. The world faces tremendous problems of hunger, overpopulation, environmental pollution, conflict between nations and conflict between poor and rich. Constructive peaceful solutions are desperately needed. But Soviet leaders consistently block such solutions and con- tribute to conflicts. One can hardly doubt the Soviet role in the oil crisis, international terrorism, the Cuban presence in Africa and the like. A principal characteristic of catastrophes is that you cannot foresee them in exact terms; to prevent them you must remove their roots long before they occur. This way I believe that even partial successes in human rights are of more relevance to avoiding nuclear war (or other catastrophes of yet unknown nature) than formal treaties, which Soviet leaders sign and ignore.

In the final analysis, your attitude toward a boycott in human rights matters depends on your acceptance of totalitarian rule as a phenomenon. Suppose you declare a limited boycott, and in response, the Soviets declare a sweeping counter-boycott, as a result of which some scientists suffer. Are you to be blamed? Those who accept totalitarianism as a reality which is unpleasant but cannot be changed, will say yes, you 'provoked' them. Those who do not accept totalitarianism will say no, for only the Soviet authorities are responsible for the repressions in the Soviet Union. In the fight for human rights you cannot count on speedy results and lose your nerve when the Soviets refuse to give in. When the Soviets realise that from now on, punishment for transgressions will be a permanent factor which they cannot change by being stubborn, the desired results will ensue. After all, the Soviet Union needs the West much more than the West needs the Soviet Union. Returning to Orlov's case, if you see totalitarianism as a horrible threat to mankind, and your mind rebels at what the Soviets are doing to Orlov and others, you will certainly not reject a boycott, although aware of its double-edged nature. If you accept totalitarianism (at least for those strange guys with 'mysterious Slav souls'), you will see Orlov's case as a sad but natural matter, something in the nature of an automobile accident: the worse for Orlov.

Feshbach et al. call for a petition. But the effect on the Soviet authorities of verbal actions has been diminishing during the past few years. Earlier, the prestige of the Soviets in the West was relatively high, and Soviet officials feared that a loss of prestige would immediately result in diminished scientific and technological cooperation. Because of this, they were rather sensitive towards criticism from scientific circles. Now they have little left to lose in the way of prestige, and they realise that they have not suffered a loss of cooperation. So why fuss about petitions and criticisms? I am not saying that petitions have become useless, but they are becoming so. To stop this trend you must do something real. In Orlov's case, a petition, signed by 220 physicists (18 February 1977), has already been issued. The only visible result has been to increase the severity of the charge against Orlov.

I am distressed by similarities in the attitude of the average American and the average Soviet person towards totalitarianism. I see the same readiness to capitulate without fight. In discussions of boycotting Soviet physics over Orlov's case, the standard response has been: "Anyway, you will not find many who agree to boycott." This is similar to what the Soviet man in the street (and the well disposed KGB officer) says to dissidents: "You will not change it, anyway."

Yurii Orlov once told me the following story. He telephoned a well-known Soviet physicist, Academician V. $\mathrm{L}$. Ginzburg, to arrange a meeting. He intended to discuss questions of physics, not of public life, so it had nothing to do with his dissident activities. But no sooner had $\mathrm{Dr}$ Ginzburg realised to whom he was speaking, than he hurried to warn: "But bear in mind: problems of the progress of mankind lie outside my interest." I am afraid now that when $I$ telephone a well-known physicist in this country, no matter what my purpose, the first thing I am going to hear will be: "But bear in mind: I am not going to boycott Soviet physics over Orlov's case." 